\title{
GLMN Gene Product
}

National Cancer Institute

\section{Source}

National Cancer Institute. GLMN Gene Product. NCI Thesaurus. Code 1131993.

A protein encoded by the GLMN gene. 